\title{
Characterization of Nitro-Aromatic Compounds of Ethylbenzene Secondary Organic Aerosol with Acidic Sodium Nitrate Fine Particles
}

\author{
Wei Zhang ${ }^{1}$, Mingqiang Huang ${ }^{1 *}$, Tingting Lu ${ }^{1}$, Shunyou Cai ${ }^{1}$, \\ Weixiong Zhao ${ }^{2}$, Changjin $\mathrm{Hu}^{2}$, Xuejun $\mathrm{Gu}^{2}$, Weijun Zhang ${ }^{2 * *}$
}

${ }^{1}$ Fujian Provincial Key Laboratory of Modern Analytical Science and Separation Technology, College of Chemistry and Chemical Engineering and Environment, Minnan Normal University, Zhangzhou 363000, China

${ }^{2}$ Laboratory of Atmospheric Physico-Chemistry, Anhui Institute of Optics and Fine Mechanics, Chinese Academy of Sciences, Hefei 230031, China

Received: 31 January 2021

Accepted: 14 May 2021

\begin{abstract}
Acidic sodium nitrate $\left(\mathrm{NaNO}_{3}\right)$ is the fine particles commonly found in urban atmosphere, which is beneficial to the formation of nitro-aromatic compounds (NACs). The NACs and optics of secondary organic aerosol (SOA) generated from the photo-oxidation of ethylbenzene with acid $\mathrm{NaNO}_{3}$ fine particles were characterized in the current study. The results demonstrated that acidic $\mathrm{NaNO}_{3}$ can significantly promote the formation of SOA. Compared with the carbonyls detected in SOA without fine particles, nitrophenols, nitrocatechols and their derivatives are measured as the major components of SOA with acid $\mathrm{NaNO}_{3}$. The $\mathrm{N}=\mathrm{O}$ chromosphore in NACs enhanced the light absorption capacity of SOA. The mass absorption coefficient averaged over 200-600 nm ( $<\mathrm{MAC}>)$ of SOA gradually increased with the increasing of acidic $\mathrm{NaNO}_{3}$. While, the $<$ MAC $>$ of SOA with $100 \mu \mathrm{g} / \mathrm{m}^{3}$ acidic $\mathrm{NaNO}_{3}$ was comparable to that of biomass burning organic aerosols. These would provide the experimental basis for studying the formation and optics of anthropogenic NACs in the background of high concentration of acid $\mathrm{NaNO}_{3}$ fine particles.
\end{abstract}

Keywords: nitro-aromatic compounds, ethylbenzene, secondary organic aerosol, sodium nitrate, fine particles

\section{Introduction}

Nitro-aromatic compounds (NACs), especially for the $-\mathrm{OH}$ and $-\mathrm{NO}_{2}$ groups attached to the aromatic

*e-mail: huangmingqiang@mnnu.edu.cn

**e-mail: wjzhang@aiofm.ac.cn ring, such as nitrophenols, nitrocatechols and their derivatives, are an important class of organic nitrogen of aerosol particles in atmosphere [1-2]. NACs have been detected in urban and rural atmosphere, with the concentrations ranged from 0.1 to $147.4 \mathrm{ng} / \mathrm{m}^{3}$ [2-4]. The observational field experiments demonstrated that biomass combustion contributed about $10-21 \%$ of the NACs in aerosol particles [5-6]. Also, NACs can 
be secondarily formed via $\mathrm{OH}$-initiated oxidation of aromatic compounds released by anthropogenic emission sources in the presence of $\mathrm{NO}_{x}$ [7-8]. As suggested by Ji et al. [9], aromatics reacted with $\mathrm{OH}$ radicals result in the formation of hydroxycyclohexadienyl radical via the major $\mathrm{OH}$ addition, which subsequent reaction with $\mathrm{O}_{2}$ lead to the formation of phenolic compounds under atmospheric condition. Phenolic products can further initiated by $\mathrm{OH}$ radical to form hydroxyphenoxy radicals, which then react with $\mathrm{NO}_{2}$ to generate NACs [7-10]. Besides to their mutagenesis and genotoxicity to humans, NACs with strong chromophore of $\mathrm{N}=\mathrm{O}$ were responsible for the light absorption by brown carbon $(\mathrm{BrC})$, contributing to radiative balance and visibility degradation [11-12]. Thus, the study of the chemical composition and formation process of NACs has great atmospheric significance.

Ethylbenzene and other aromatic compounds are expected to be vital precursors of NACs in urban atmospheres [13-15]. OH-initiated photo-oxidation of aromatic compounds in the presence of $\mathrm{NO}_{\mathrm{x}}$ leading to the formation of nitrophenols, dinitrophenols and other NACs, which result in the formation of secondary organic aerosol (SOA) particles [7-10, 13-15]. Compared with the gaseous formation of NACs, aqueous aromatic nitration is another formation pathway of NACs [16-17]. For example, nitrophenols can be formed via the hydroxylation and nitration of benzene upon UV irradiation of nitrite in aqueous solutions [16]. Some of the aromatic compounds emitted to the atmosphere remain in the gas phase were oxidized by $\mathrm{OH}$ radicals and $\mathrm{NO}_{\mathrm{x}}$ to produce NACs. The other part entered into the aqueous phase such as liquid aerosol particle, water droplet, and cloud in the atmosphere. When nitrite exists in the aqueous phase, NACs can be generated under ultraviolet light [8, 18]. However, the aqueous formation pathway of NACs is less well-understood.

Owing to the development of China's economy, the number of motor vehicles is increasing, the use of fossil fuels in large quantities, and the urban atmosphere contains relatively large concentrations of acidic inorganic fine particles [19-20]. For example, the concentration of $\mathrm{Na}^{+}, \mathrm{H}^{+}, \mathrm{NH}_{4}^{+}, \mathrm{NO}_{3}{ }^{-}$and other inorganic ions in fine particles achieved $100-300 \mu \mathrm{g} / \mathrm{m}^{3}$ during hazy days in Beijing and Shanghai [21-23]. Therefore, there is high concentration of acid sodium nitrate $\left(\mathrm{NaNO}_{3}\right)$ fine particle in Chinese urban atmosphere $[19,20]$. These fine particles have large specific surface area, which can become the center of condensation and heterogeneous reactions of semi-volatile compounds [24]. In addition, the surface of fine acidic $\mathrm{NaNO}_{3}$ particles absorbs moisture to form the liquid aerosol, and the $\mathrm{H}^{+}$and $\mathrm{NO}_{3}{ }^{-}$can generate $\mathrm{OH}$ and $\mathrm{NO}_{2}$ radicals via photolysis upon UV irradiation [25], which is beneficial to the formation of NACs. Therefore, the study of the influence of high concentration of acidic $\mathrm{NaNO}_{3}$ fine particles on the formation of aromatic SOA and the composition of NACs is helpful to understand the aqueous formation mechanism of NACs. Recently, our group has performed the influence of inorganic fine particles such as ammonium sulfate and calcium chloride on the chemical composition of toluene, 1,3,5-trimethylbenzene in smog chamber [26-28]. So, $\mathrm{PM}_{2.5}$ particle detector, UV-Vis spectrophotometer (UV-Vis) and liquid chromatography-mass spectrometry (LC-MS) were utilized to measure the ethylbenzene SOA of different concentrations of acidic $\mathrm{NaNO}_{3}$ fine particles in this study. The influence of acidic $\mathrm{NaNO}_{3}$ fine particles on the NACs composition and optical properties of ethylbenzene SOA were discussed. These would provide experimental basis for studying the formation mechanism of NACs under the background of acidic inorganic fine particles.

\section{Experimental}

\section{Materials}

Ethylbenzene (>99\%) and hydrogen peroxide (30\%) were obtained from Sigma-Aldrich Chemistry Corporation, Germany. Methanol (>99\%), nitric acid (65-68\%) and sodium nitrate $(99.9 \%)$ were supplied by the Third Reagent Factory of Tianjin.

Acidic inorganic fine particles were produced by aspirating the $0.001 \mathrm{~mol} / \mathrm{L} \mathrm{NaNO}_{3}$ and $\mathrm{HNO}_{3}$ mixed solution via the atomizer (TSI Inc. Model 3076, USA), passed through a dryer (TSI Inc. Model 3062, USA) and a neutralizer (TSI Inc., Model 3054, USA), and then introduced into the chamber [26-28]. The diameter of the acidic $\mathrm{NaNO}_{3}$ fine particles was less than $2 \mu \mathrm{m}$, while the concentration was established at a certain value through controlling the filling time of the fine particles into the chamber.

\section{Ethylbenzene SOA Formation without and with Acidic $\mathrm{NaNO}_{3}$ Fine Particles}

Formation of ethylbenzene SOA particles without and with different concentration of acidic $\mathrm{NaNO}_{3}$ fine particles was performed in home-made chamber [26-28]. Ethylbenzene, hydrogen peroxide and acidic $\mathrm{NaNO}_{3}$ fine particles were delivered to chamber, which was then filled with zero air to full volume. The concentration of ethylbenzene and hydrogen peroxide was fixed as $1 \mathrm{ppm}$ and $10 \mathrm{ppm}$, respectively. 8 experiments were carried out in the absence and presence of acidic $\mathrm{NaNO}_{3}$ fine particles in the concentration of $25,50,75,100,150,200$ and $300 \mu \mathrm{g} / \mathrm{m}^{3}$, respectively. The temperature and relative humidity in chamber was about $298 \mathrm{~K}$ and $37 \%$. Four UV lamps were used to irradiate hydrogen peroxide to form $\mathrm{OH}$ radicals [29], which initiated the oxidation of ethylbenzene to generate SOA. The concentration of ethylbenzene and SOA particles in the chamber was detected using GC-FID (Agilent 7820A, USA) and $\mathrm{PM}_{2.5}$ particle detector (Shenzhen Huashengchang 
Machinery Industry Co., Ltd, CEM-DT96, China). Each experiment was performed for 3 times, the averaged results were utilized as the final data.

\section{Chemical Characterization of NACs in Ethylbenzene SOA Using UV-Vis and LC-MS}

After photo-oxidation, the ethylbenzene SOA was collected onto the polytetrafluoroethylene membrane filter and extracted into $2 \%$ methanol solution using sonication. The UV-Vis spectra of the extract solutions were measured by double beam UV-6100S spectrophotometer (Mapada Instruments, China). Also, extract solutions were detected by LC-MS equipped with electrospray ionization (ESI) (Agilent-1200, Agilent-6320, USA). The mobile phase was methanol and ultra-pure water $(1: 1 \mathrm{v} / \mathrm{v})$ with the rate of $0.20 \mu \mathrm{L} / \mathrm{min}$. Each sample was detected without LC column, and measured in the range of 50-1000 amu of the negative mode [30].

\section{Optical Characterization of Ethylbenzene SOA}

Mass absorption coefficient (MAC) is often utilized to characterize the optical properties of aerosol particles. Aerosol samples were collected by membrane sampler, and the soluble components in the particles were extracted by water or methanol. The absorbance was obtained by measuring the light attenuation after the light passed through the extract solution with the help of ultraviolet visible spectrophotometer. The MAC parameters were obtained according to the length of the absorption cell and the concentration of organic matter in the sample [31-32]:

$$
\begin{gathered}
\operatorname{MAC}(\lambda)=\frac{A^{\text {solution }}(\lambda) \times \ln 10}{b \times C_{\text {mass }}} \\
\langle M A C\rangle=\frac{1}{\left(\lambda_{2}-\lambda_{1}\right)} \times \int_{\lambda_{1}}^{\lambda_{2}} M A C(\lambda) d \lambda
\end{gathered}
$$

...where $\mathrm{A}^{\text {solution }}$ in formula (1) is the absorbance of the extract at a specific wavelength $(\lambda), \ln 10$ is a constant, $\mathrm{b}$ is the optical path length, and $\mathrm{C}_{\text {mass }}$ is the mass concentration of SOA organic carbon in the extract solution. According to formula (2), the averaged MAC value $<$ MAC $>$ is obtained by integrating in the measurement wavelength range $\left(\lambda_{1}-\lambda_{2}\right)$. The absorption spectrum and total organic carbon concentration of the ethylbenzene SOA extract solutions at 200-600 nm were measured by UV-6100S spectrophotometer and total organic carbon analyzer (TOC-L, Shimadzu Company, Japan). The mass absorption coefficient averaged over 200-600 nm $(<\mathrm{MAC}>)$ of ethylbenzene SOA was obtained according to formula (1) and (2).

\section{Results}

\section{Formation of Ethylbenzene SOA without and with Acidic $\mathrm{NaNO}_{3}$ Fine Particles}

The formation of ethylbenzene SOA without fine particles was measured firstly. For the mixed gases of $1 \mathrm{ppm}$ ethylbenzene and $10 \mathrm{ppm}$ hydrogen peroxide, the concentration of SOA with irradiation time measured by $\mathrm{PM}_{25}$ particle detector was shown in Fig. 1. In the first $15 \mathrm{~min}$, few particles $\left(4 \mu \mathrm{g} / \mathrm{m}^{3}\right)$ were detected by $\mathrm{PM}_{2.5}$ particle detector. $\mathrm{OH}$ radicals formed from the photolysis of hydrogen peroxide reacted with ethylbenzene to generate semi- and nonvolatile products $[15,33]$. These products nucleated and condensed to form SOA particles after reaching their saturated vapor pressure. Thus, few particles were formed until the certain amount of ethylbenzene reacted to yield gaseous concentrations that exceed saturation vapor pressure. In the following $15 \sim 180 \mathrm{~min}$, more photo-oxidation products are formed to participate in the process of gas/particle partitioning [34], and the mass concentration of SOA gradually increases. At $180 \mathrm{~min}$ of illumination reaction, ethylbenzene is not detected by GC-FID, while the concentration of SOA in the chamber reached the maximum value of $105 \mu \mathrm{g} / \mathrm{m}^{3}$. Thereafter, no ethylbenzene to react to generate particles, the concentration of SOA decreased gradually due to the chamber wall effect [26-28].

For the experiments of acid $\mathrm{NaNO}_{3}$ fine particles, the concentration of ethylbenzene SOA was obtained via subtracting the concentration of acid $\mathrm{NaNO}_{3}$ particles from the aerosol mass concentration measured by $\mathrm{PM}_{2.5}$ particle detector. As displayed in Fig. 1, the curve of the concentration of ethylbenzene SOA with $100 \mu \mathrm{g} / \mathrm{m}^{3}$ acidic $\mathrm{NaNO}_{3}$ fine particles with illumination time is similar to the case of without fine particles. Nevertheless, the maximum concentration of ethylbenzene SOA in the chamber achieved

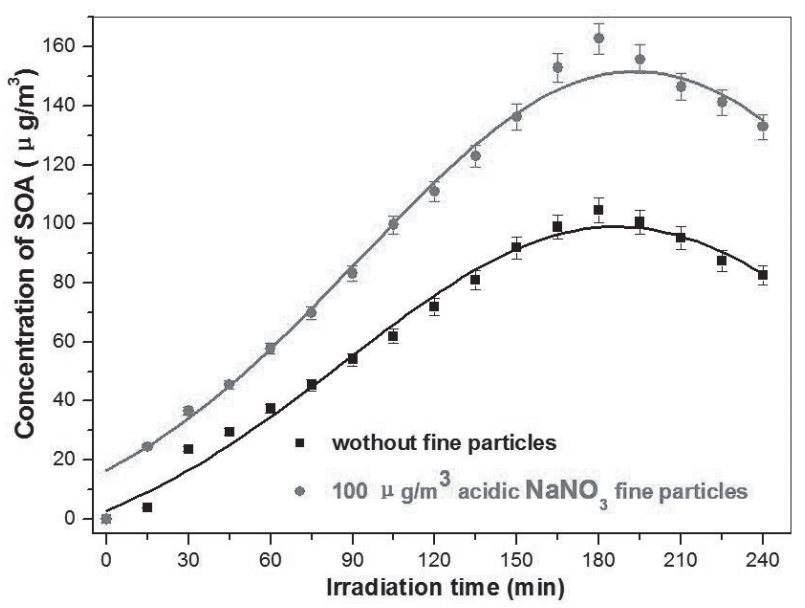

Fig. 1. The concentration of ethylbenzene SOA at different irradiation time in the absence of and presense of $100 \mu \mathrm{g} / \mathrm{m}^{3}$ acidic $\mathrm{NaNO}_{3}$ fine particles. 


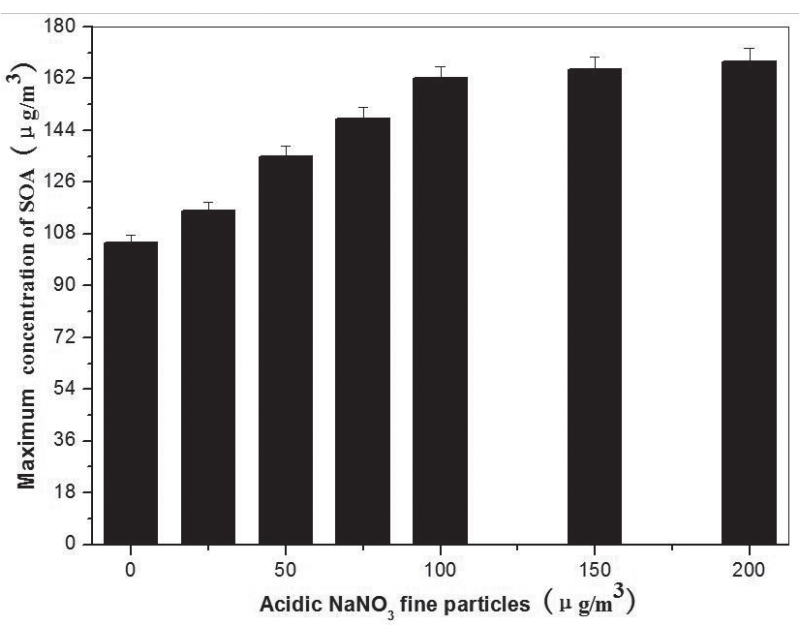

Fig. 2. The maximum concentration of ethylbenzene SOA in the presence of different concentrations of acidic $\mathrm{NaNO}_{3}$ fine particles.

$162 \mu \mathrm{g} / \mathrm{m}^{3}$ when illuminated for $180 \mathrm{~min}$, which was $54 \%$ higher than that without fine particles. In addition, the maximum concentration of SOA produced by 1 ppm ethylbenzene and $10 \mathrm{ppm}$ hydrogen peroxide in the presence of different concentrations of acidic $\mathrm{NaNO}_{3}$ fine particles as illustrated in Fig. 2 is about $116-168 \mu \mathrm{g} / \mathrm{m}^{3}$, which is greater than the maximum mass concentration of SOA produced without fine particles $\left(105 \mu \mathrm{g} / \mathrm{m}^{3}\right)$. These demonstrated that the acidic $\mathrm{NaNO}_{3}$ fine particles promote the formation of ethylbenzene SOA. It is worth noting that the maximum concentration of ethylbenzene SOA did not continue to increase when the concentration of acid $\mathrm{NaNO}_{3}$ fine particles was greater than $100 \mu \mathrm{g} / \mathrm{m}^{3}$. In order to further characterize the chemical composition of ethylbenzene SOA, $\mathrm{UV}-\mathrm{V}$ is and LC-MS measurements were performed in the following section.

\section{Characterization of NACs in Ethylbenzene SOA with Acidic $\mathrm{NaNO}_{3}$ Fine Particles}

The OH-initiated photo-oxidation of ethylbenzene generates ethyl benzyl radical and ethyl hydroxycyclohexadienyl through hydrogen abstraction and $\mathrm{OH}$ addition $[33,35-36]$. As displayed in Fig. 3, the ethyl benzyl radical can react with $\mathrm{O}_{2}$ leading to the formation of phenylacetaldehyde, and the ethyl hydroxycyclohexadienyl radical reacted with $\mathrm{O}_{2}$ to generate ethylphenol and peroxy radical. The latter undergone reactions to form glyoxal, 2-ethyl-2,4hexadienedial and other aldehydes [33, 35-36]. Also, the formed aldehydes, like phenylacetaldehyde, glyoxal can be oxidized by $\mathrm{OH}$ radical and $\mathrm{O}_{2}$ and to phenylacetic acid and glyoxylic acid $[6,33]$. As suggested by Fan and Zhang [37], the channel of ethyl hydroxycyclohexadienyl radical reaction with $\mathrm{O}_{2}$ to form ethylphenol was relatively minor, indicating that carbonyls are the major constituents of ethylbenzene SOA without acidic $\mathrm{NaNO}_{3}$ fine particles. This was confirmed by the ESI-MS and UV-Vis spectra of ethylbenzene SOA particles in the absence of fine particles displayed in Fig. 4 and Fig. 5. According to the experimental results of Carlton et al. [38], the molecular-related ions $[\mathrm{M}-\mathrm{H}]^{-}$provided the information of molecular weights of organics. The $[\mathrm{M}-\mathrm{H}]^{-}$ions of carbonyls, such as

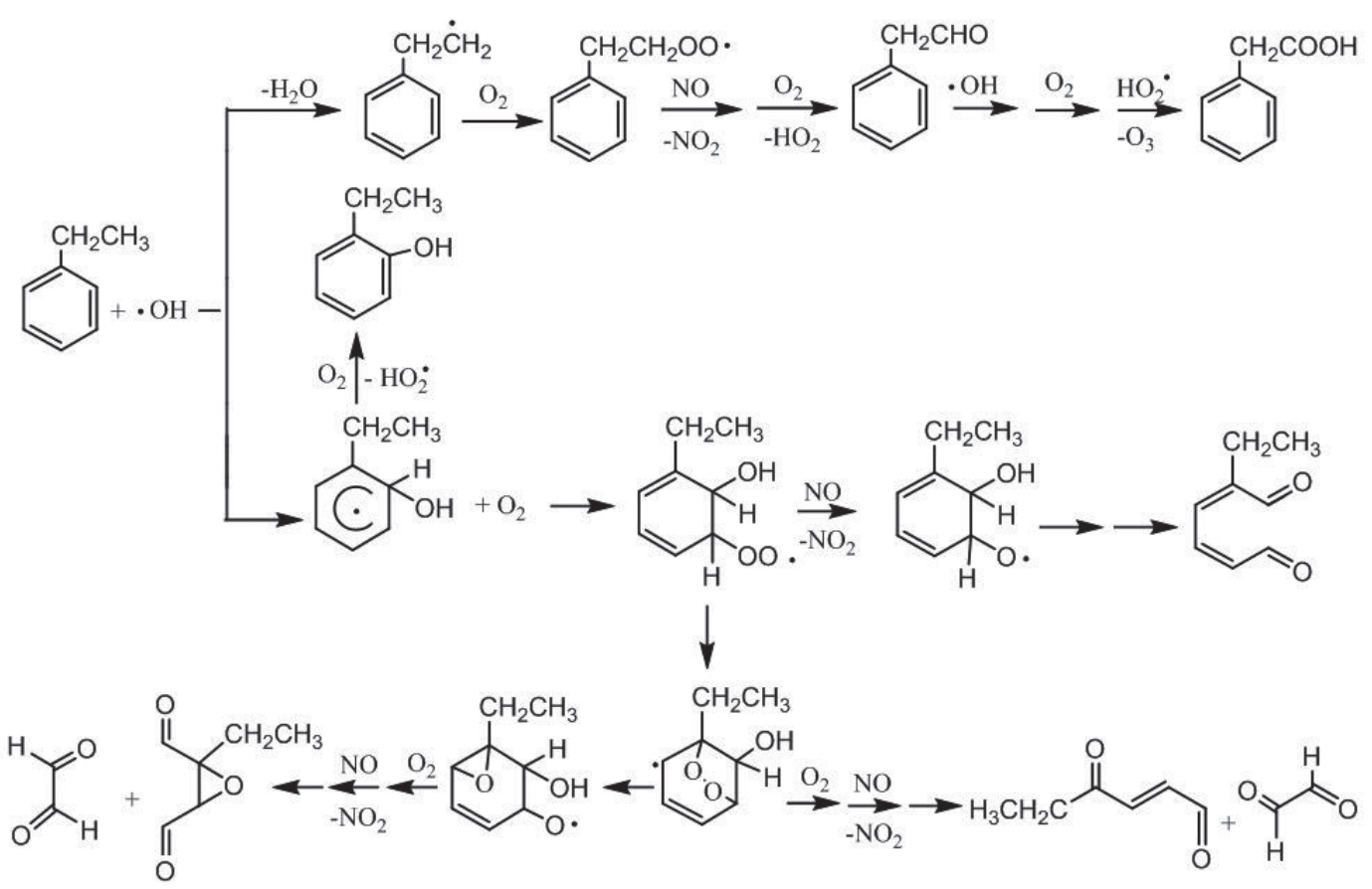

Fig. 3. Proposed reaction mechanism for the $\mathrm{OH}$-initiated photo-oxidation of ethylbenzene leading to the formation of carboxyl compounds. 


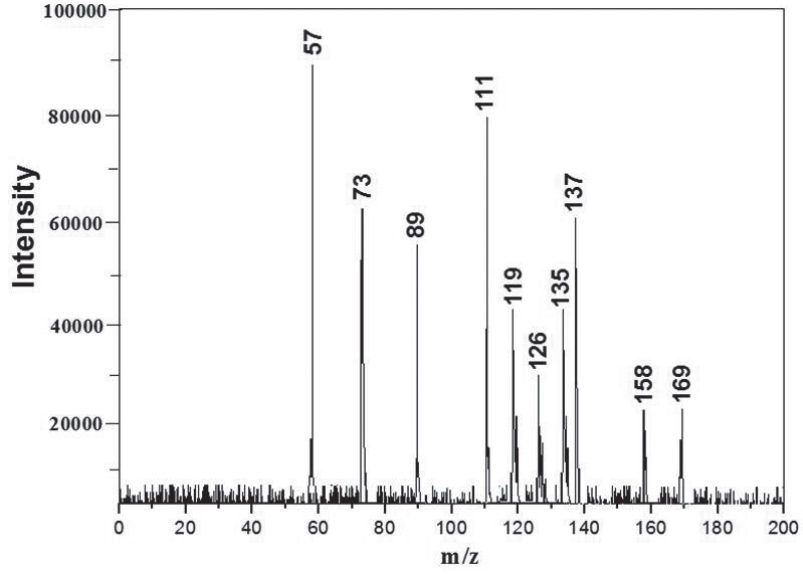

Fig. 4. Negative ion mass spectra of ethylbenzene SOA particles without acidic $\mathrm{NaNO}_{3}$ fine particles.

glyoxal (m/z 57), glyoxylic acid (m/z 73), oxalic acid (m/z 89), 4-oxo-2-hexenal (m/z 111), phenylacetaldehyde (m/z 119), 2-ethyl-2,3-epoxy-butanedial (m/z 126), phenylacetic acid $(\mathrm{m} / \mathrm{z}$ 135), 2-ethyl-2,4-hexadienedial ( $\mathrm{m} / \mathrm{z}$ 137), 2-ethyl-2,3-epoxy-succinic acid (m/z 158) and 2-ethyl-2,4-hexadienedioic acid (m/z 169) are appeared clearly in the negative ESI-MS spectra shown in Fig. 4. Also, the peak at $205 \mathrm{~nm}$ of characteristic absorption of carbonyls [38] is presented in the UV-Vis spectra as displayed in Fig. 5a).

Different from the absorption peak at $205 \mathrm{~nm}$ of ethylbenzene SOA without fine particles, the absorption peak in the UV-Vis spectra of ethylbenzene SOA particles with $100 \mu \mathrm{g} / \mathrm{m}^{3}$ acidic $\mathrm{NaNO}_{3}$ fine particles shown in Fig. 5b) was significantly redshifted to $365 \mathrm{~nm}$. This peak was also observed in the UV-Vis spectra of brown carbon constituents of toluene SOA with $\mathrm{NO}_{x}$ conducted by Lin et al. [13]. They considered nitrophenols of NACs, such as nitrophenol, nitrocatechol and dinitrophenol were responsible for the

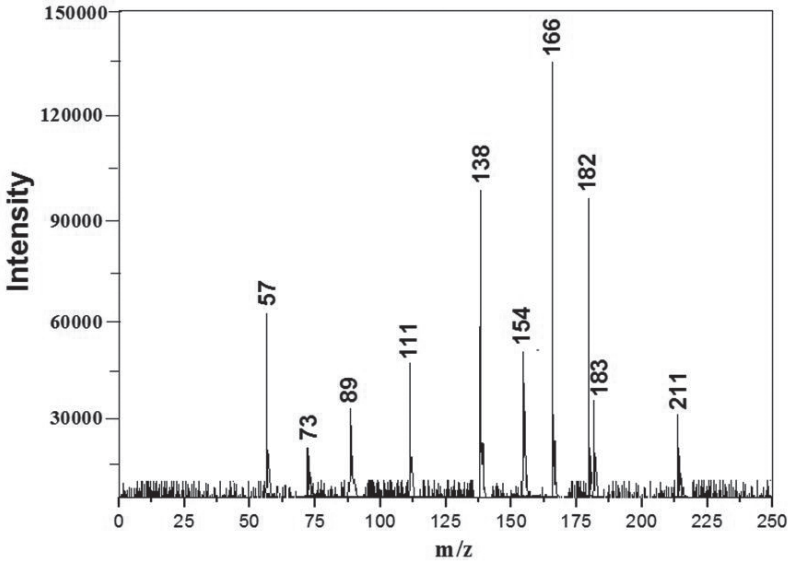

Fig. 6. Negative ion mass spectra of ethylbenzene SOA particles with $100 \mu \mathrm{g} / \mathrm{m}^{3}$ acidic $\mathrm{NaNO}_{3}$ fine particles.

light absorption of toluene SOA with $\mathrm{NO}_{\mathrm{x}}$, the $\mathrm{n} \rightarrow \pi^{*}$ transition in the $\mathrm{N}=\mathrm{O}$ was the principal contributor to the absorption peak at $365 \mathrm{~nm}$. In addition, the obtained mass spectra of ethylbenzene SOA particles with $100 \mu \mathrm{g} / \mathrm{m}^{3}$ acidic $\mathrm{NaNO}_{3}$ fine particles shown in Fig. 6 contained the $[\mathrm{M}-\mathrm{H}]^{-}$ions of nitrophenols, such as 3-nitro-phenol (m/z 138), 3-nitro-catechol $(\mathrm{m} / \mathrm{z}$ 154), 3-nitro-o-ethylphenol (m/z 166), 5-nitro-3-ethylcatechol (m/z 182), 3,5-dinitro-phenol $(\mathrm{m} / \mathrm{z} 183)$ and 3,5-dinitro-o-ethylphenol ( $\mathrm{m} / \mathrm{z} 211)$, confirming that the $365 \mathrm{~nm}$ chromosphore correspond to nitrophenols.

\section{Optical Characterization of NACs in Ethylbenzene SOA}

Aerosol particles can affect atmospheric visibility through light absorption. Updyke et al. [31] and Powelson et al. [32] used the averaged mass absorption coefficient $<$ MAC $>$ to quantify the effect of aerosol light absorption. The total organic carbon concentration of ethylbenzene SOA with different concentrations of acid
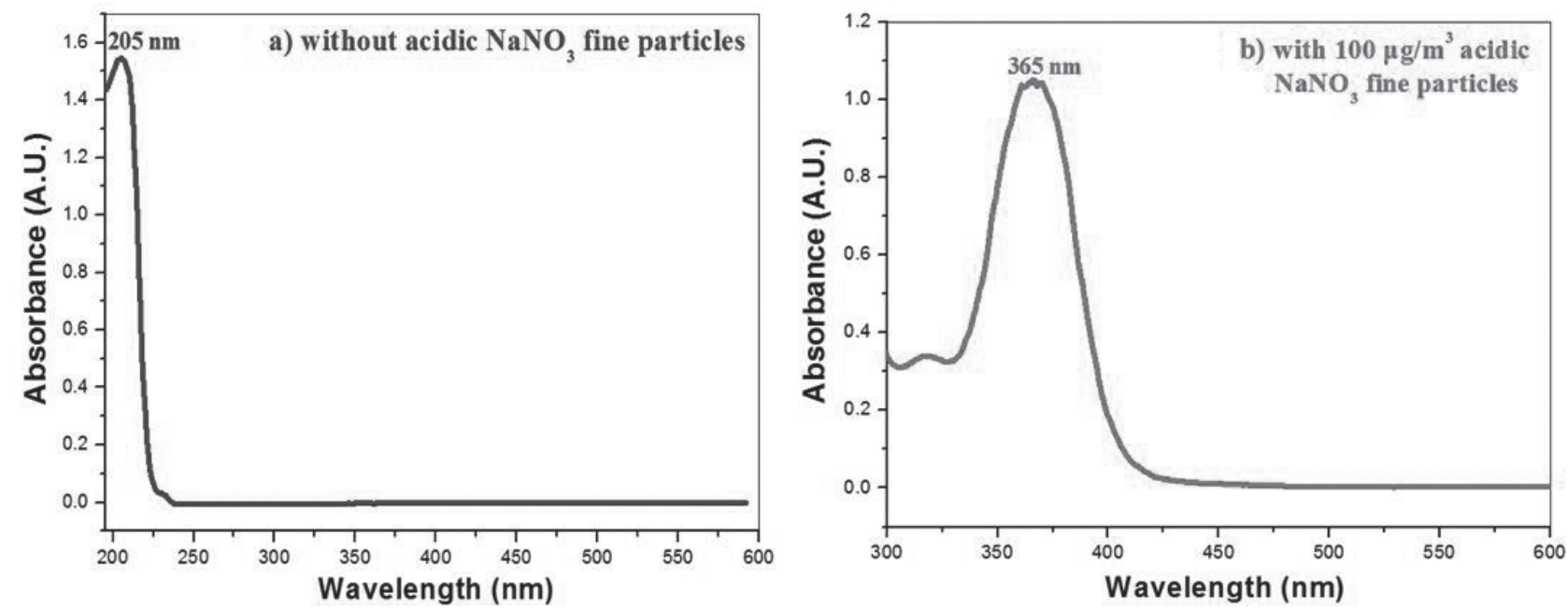

Fig. 5. The UV-Vis spectra of ethylbenzene SOA particles a) without and b) with $100 \mu \mathrm{g} / \mathrm{m}^{3}$ acidic $\mathrm{NaNO}_{3}$ fine particles. 


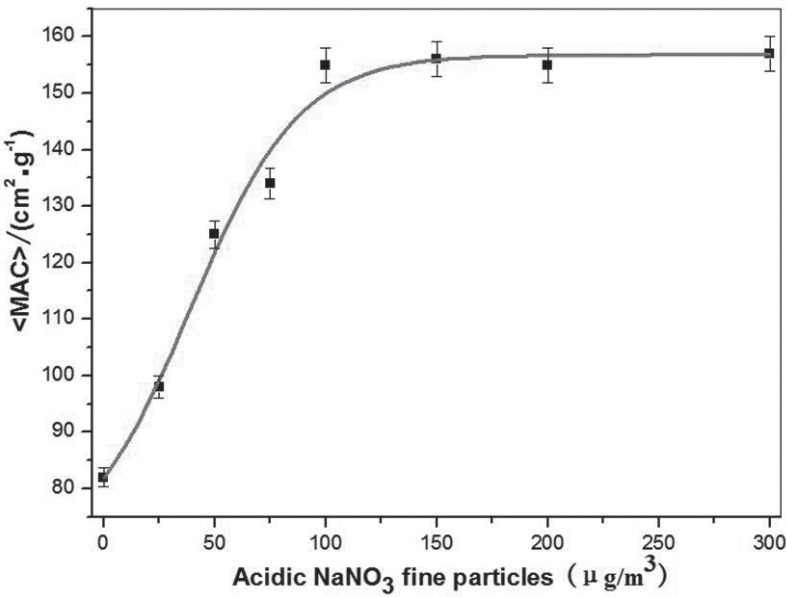

Fig. 7. The averaged mass absorption coefficient $(<\mathrm{MAC}>)$ of ethylbenzene SOA in the presence of different concentrations of acidic $\mathrm{NaNO}_{3}$ fine particles.

$\mathrm{NaNO}_{3}$ fine particles was measured by the total organic carbon analyzer. Combined with the UV-Vis spectra of SOA collection solution in the range of 200-600 nm, the $<$ MAC $>$ value was calculated according to the formula (1) and (2). As shown in Fig. 7, in the absence of fine particles, the $\langle$ MAC $>$ value of ethylbenzene SOA in the range of $200-600 \mathrm{~nm}$ is $82 \mathrm{~cm}^{2} \cdot \mathrm{g}^{-1}$, which is slightly larger than that of 1,3,5-trimethylbenzene SOA particles $\left(70 \mathrm{~cm}^{2} \bullet \mathrm{g}^{-1}\right)$ measured by Updyke et al. [31]. As mentioned above, aldehydes and carboxylic acids are the principal components of ethylbenzene SOA without fine particles. These compounds only contained
$\mathrm{C}=\mathrm{O}$ and $\mathrm{C}=\mathrm{C}$, did not have strong chromosphores and auxochromes [11, 39]. Therefore, ethylbenzene SOA without fine particles had weak absorbability.

The $<$ MAC $>$ value of ethylbenzene SOA particles increased significantly with the presence of acidic $\mathrm{NaNO}_{3}$ particles, and gradually increased with the increase of the concentration of acidic $\mathrm{NaNO}_{3}$ particles (Fig. 7). The $<\mathrm{MAC}>$ value of ethylbenzene SOA in the range of $200-600 \mathrm{~nm}$ with $100 \mu \mathrm{g} / \mathrm{m}^{3}$ acidic $\mathrm{NaNO}_{3}$ fine particles is $155 \mathrm{~cm}^{2} \cdot \mathrm{g}^{-1}$, which is in the range of the $<\mathrm{MAC}>$ value of organic aerosol from biomass burning $\left(100-700 \mathrm{~cm}^{2} \cdot \mathrm{g}^{-1}\right)$ measured by Chakrabarty et al. [40], and is $89 \%$ higher than that of ethylbenzene SOA without fine particles $\left(82 \mathrm{~cm}^{2} \cdot \mathrm{g}^{-1}\right)$. This is mainly because NACs are the main components of ethylbenzene SOA with acidic $\mathrm{NaNO}_{3}$ particles. The $\mathrm{N}=\mathrm{O}$ chromosphore in NACs enhances the light absorption capacity of SOA. However, when acidic $\mathrm{NaNO}_{3}$ fine particles exceed 100 $\mu \mathrm{g} / \mathrm{m}^{3}$, the $<\mathrm{MAC}>$ of ethylbenzene SOA was nearly keep constant as illustrated in Fig. 7.

\section{Discussion}

\section{Effects of Acidic $\mathrm{NaNO}_{3}$ Fine Particles on the NACs of Ethylbenzene SOA}

The proposed model of formation mechanism of nitrophenols in the presence of acidic $\mathrm{NaNO}_{3}$ fine particles is shown in Fig. 8. In the presence of acidic $\mathrm{NaNO}_{3}$ fine particles, the formed gaseous products can coagulate on the aqueous surface of fine particles to form SOA before arriving its saturated vapor pressure

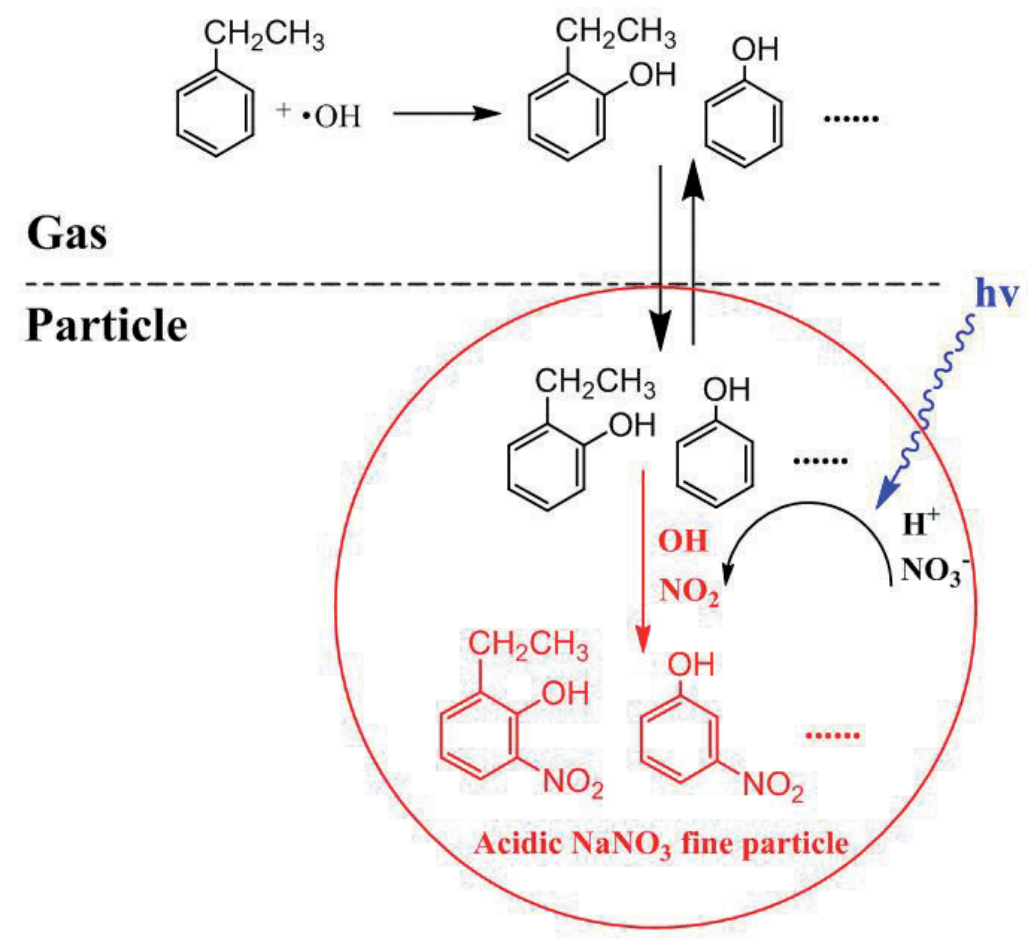

Fig. 8. The proposed model of formation mechanism of nitrophenols in the presence of acidic $\mathrm{NaNO}_{3}$ fine particles. 
[26]. As suggested by Vione et al. [16], the $\mathrm{H}^{+}$and $\mathrm{NO}_{3}^{-}$ can generate $\mathrm{OH}$ and $\mathrm{NO}_{2}$ radicals via photolysis upon UV irradiation:

$$
\mathrm{NO}_{3}^{-}+\mathrm{h} v+\mathrm{H}^{+} \rightarrow \mathrm{OH}+\mathrm{NO}_{2}
$$

These two radicals reacted with the coagulated phenolic products of ethylbenzene to yield NACs via the hydroxylation and nitration. As displayed in Fig. 9, OH radical can extract the hydrogen atom of phenolic hydroxyl group of o-ethylphenol to generate o-ethylphenoxy radical, which further reacted with $\mathrm{NO}_{2}$ radical to form 3-nitro-o-ethylphenol and 3,5-dinitroo-ethylphenol, respectively $[7,13]$. In addition, $\mathrm{OH}$ radical can also be added to o-ethylphenol to form 3 -ethyl-catechol, which continued to react with $\mathrm{OH}$ and $\mathrm{NO}_{2}$ radicals to yield 5-nitro-3-ethyl-catechol [7,13]. As suggested by Noda et al. [41] that the dealkylation of alkylbenzenes was the significant reaction path for the generation of phenolic compounds. Phenol is also produced by de-ethylation after $\mathrm{OH}$ radical added to the ipso position of benzene ring. Similarly, phenol reacted with $\mathrm{OH}$ and $\mathrm{NO}_{2}$ radicals to generate 3-nitro-phenol, 3,5-dinitro-phenol and 3-nitro-catechol as outlined in Fig. 9. There was competition between the pathway of phenolic and carbonyl products from the photo-oxidation of ethylbenzene [33, 35-36]. Since the formed gaseous phenolic products immediately condensed and nitrated on the surface of acid $\mathrm{NaNO}_{3}$ fine particles to form NACs, the reaction of $\mathrm{OH}$ radical and ethylbenzene was mainly in the direction of generating phenolic products.
Thus, NACs are the main components of ethylbenzene $\mathrm{SOA}$ with acid $\mathrm{NaNO}_{3}$ fine particles.

\section{Effects of Acidic $\mathrm{NaNO}_{3}$ Fine Particles on the $<\mathrm{MAC}>$ of Ethylbenzene SOA}

The acidic $\mathrm{NaNO}_{3}$ fine particles have large specific surface area and can provide the reaction center for the formation of NACs [26]. The high concentration of acidic $\mathrm{NaNO}_{3}$ fine particles provided more surface area for condensation and reaction of phenolic compounds. So, nitrophenols of NACs and the $<$ MAC $>$ of SOA increased with the concentration of acidic $\mathrm{NaNO}_{3}$ fine particles. However, the concentration of ethylbenzene and hydrogen peroxide were nearly constant for every experiment, and the formed phenol and ethyl-phenol were basically unchanged. When acidic $\mathrm{NaNO}_{3}$ fine particles were increased to a certain concentration (100 $\mu \mathrm{g} / \mathrm{m}^{3}$ ), all the phenol and ethyl-phenol were completely consumed, and the generation of nitrophenols would not increase with the increasing of the concentration of acidic $\mathrm{NaNO}_{3}$ fine particles. Thus, the $<\mathrm{MAC}>$ of ethylbenzene SOA remain basically unchanged when acidic $\mathrm{NaNO}_{3}$ fine particles exceed $100 \mu \mathrm{g} / \mathrm{m}^{3}$ as illustrated in Fig. 7.

Compared to the experiments of Sato et al [7] and Liu et al [13], which detected NACs of nitrophenols as major light-absorption products for benzene, toluene and 1,3,5-trimethyl benzene SOA particles with $\mathrm{NO}_{x}$, our study chemical characterized the NACs components of ethylbenzene SOA with different concentrations of

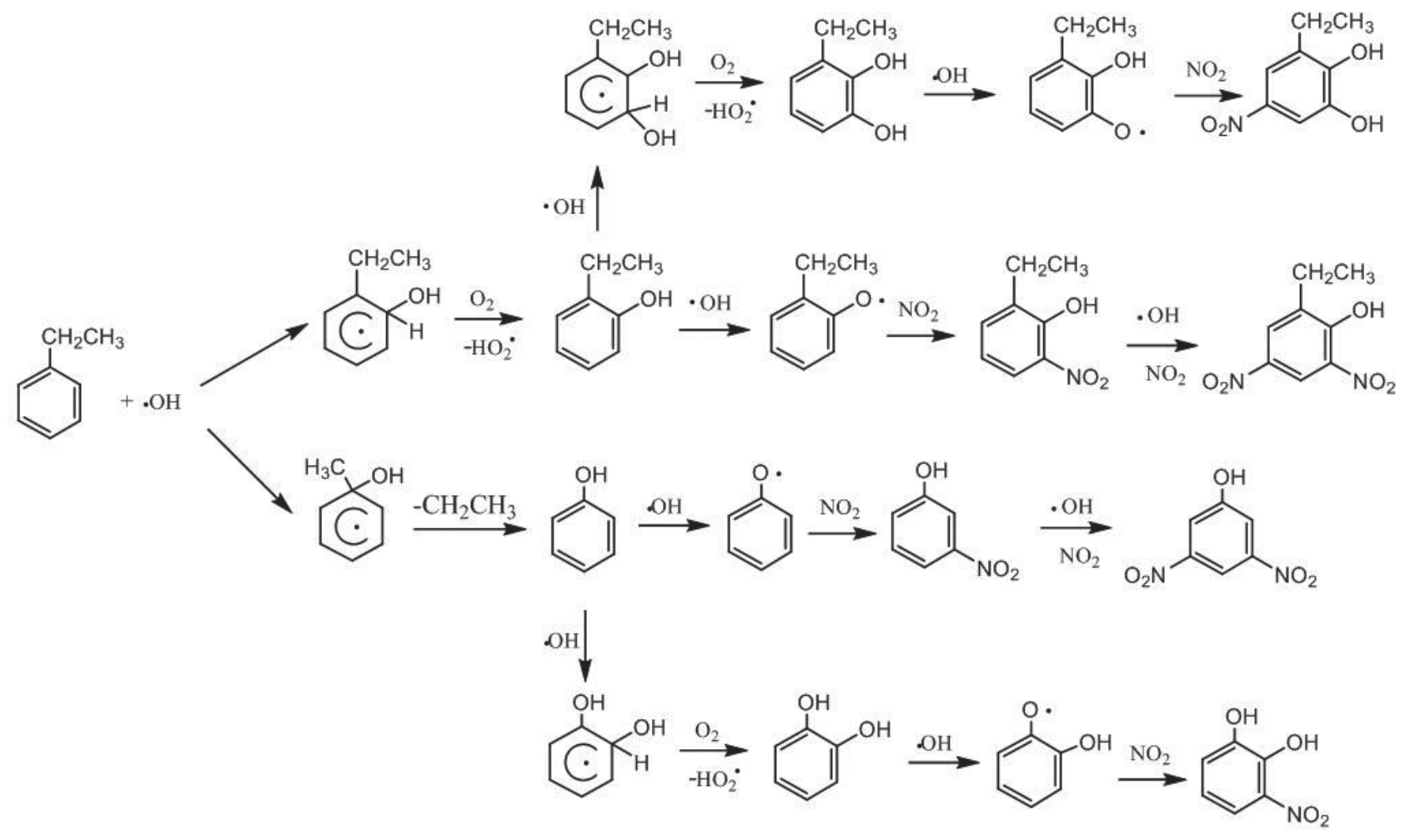

Fig. 9. Proposed reaction mechanism leading to the formation of nitrophenols. 
acidic $\mathrm{NaNO}_{3}$ fine particles, and the mass absorption coefficient averaged over 200-600 nm $(<$ MAC $>$ ) of SOA were measured by the UV-Vis spectrophotometer and total organic carbon analyzer. From ESI-MS and UV-Vis spectra of ethylbenzene SOA, we affirmed that nitrophenols, nitrocatechols and their derivatives are the principal NACs constituents in SOA with acidic $\mathrm{NaNO}_{3}$ fine particles. The $\langle\mathrm{MAC}\rangle$ of ethylbenzene SOA with $100 \mu \mathrm{g} / \mathrm{m}^{3}$ acidic $\mathrm{NaNO}_{3}$ fine particles was comparable to that of biomass burning organic aerosols (BBOAs), and was greater than that of SOA without fine particles. The increase of electrophilic nitro groups strengthened the light absorption ability of SOA. As the rate generation of SOA was greater than that of BBOAs [42], the aromatic SOA particles with high concentration of acidic $\mathrm{NaNO}_{3}$ fine particles would the major contributor to the climate forcing in urban atmosphere.

\section{Conclusions}

Nitro-aromatic compounds are important contributors to the light absorption by brown carbon. Aromatic compounds are the vital precursors of NACs in urban atmospheres. $\mathrm{PM}_{2.5}$ particle detector, UV-Vis spectrophotometer, LC-MS and total organic carbon analyzer were used to measure the mass concentration, NACs composition and the mass absorption coefficient averaged over $200-600 \mathrm{~nm}(<\mathrm{MAC}>)$ of ethylbenzene SOA with different acidic $\mathrm{NaNO}_{3}$ fine particles in this study. The obtained absorption and mass spectra showed that carbonyl compounds were the main component of ethylbenzene SOA without fine particles. Due to the large specific surface area and water absorption of acidic $\mathrm{NaNO}_{3}$ fine particles, and the gaseous phenolic products from the photo-oxidation of ethylbenzene condensed and nitrated on the surface of the fine particles to form nitrophenols, nitrocatechols and other NACs, thus significantly promoting the formation of ethylbenzene SOA. The $\langle\mathrm{MAC}\rangle$ value of SOA gradually increased with the increasing of the concentration of acidic $\mathrm{NaNO}_{3}$ particles, and the $<$ MAC $>$ of SOA with $100 \mu \mathrm{g} / \mathrm{m}^{3}$ acidic $\mathrm{NaNO}_{3}$ particles is close to that of biomass burning organic aerosols. However, the $<$ MAC $>$ value of SOA was measured by off-line method, optical parameters such as extinction and scattering coefficient of SOA should be detected on-line in the subsequent experiments.

\section{Acknowledgments}

Our work was supported by the National Natural Science Foundation of China (No. 41575118), the Key Project of the Natural Science Foundation of Fujian Province of China (No.2020J02044) and the advanced science and technology project of Minnan Normal University (No. 4201-L11805).

\section{Conflict of Interest}

The authors declare no conflict of interest.

\section{Reference}

1. YUAN W., HUANG R.J., YANG L., GUO J., CHEN Z.Y., DUAN J., WANG T., NI H.Y., HAN Y.M., LI Y.J, CHEN Q., CHEN Y., HOFFMANN T., O'DOWD C. Characterization of the light-absorbing properties, chromophore composition and sources of brown carbon aerosol in Xi'an, northwestern China, Atmos. Chem. Phys. 20 (8), 5129, 2020.

2. WANG Z.H., ZHANG J.Y., ZHANG L.Z., LIANG Y.M., SHI Q. Characterization of nitroaromatic compounds in atmospheric particulate matter from Beijing. Atmos. Environ. 246 (118046), 1, 2021.

3. TEICH M., VAN PINXTEREN D., WANG M., KECORIUS S., WANG Z., MÜLLER T., MŎCNIK G., HERRMANN H. Contributions of nitrated aromatic compounds to the light absorption of water soluble and particulate brown carbon in different atmospheric environments in Germany and China. Atmos. Chem. Phys. 17 (3), 1653, 2017.

4. CHOW K.S., HUANG X.H.H., YU J.Z. Quantification of nitroaromatic compounds in atmospheric fine particulate matter in Hong Kong over 3 years: field measurement evidence for secondary formation derived from biomass burning emissions. Environ. Chem. 13 (4), 665, 2016.

5. MOHR C., LOPEZ-HILFIKER F.D., ZOTTER P., PREVOT A.S., XU L.,NG N.L., HERNDON S.C., WILLIAMS L.R., FRANKLIN J.P.,ZAHNISER M.S., WORSNOP D.R., KNIGHTON W.B., AIKEN A.C., GORKOWSKI K.J., DUBEY M.K., ALLAN J.D., THORNTON J.A. Contribution of nitrated phenols to wood burning brown carbon light absorption in Detling, United Kingdom during winter time. Environ. Sci. Technol. 47 (12), 6316, 2013.

6. WANG X.F., GU R.R., WANG L.W., XU W.X., ZHANG Y.T., CHEN B., LI W.J., XUE L.K., CHEN J.M., WANG W.X. Emissions of fine particulate nitrated phenols from the burning of five common types of biomass. Environ. Pollut. 230, 405, 2017.

7. SATO K., TAKAMI A., KATO Y., SETA T., FUJITANI Y., HIKIDA T., SHIMONO A., IMAMURA T. AMS and LC/MS analyses of SOA from the photo-oxidation of benzene and 1,3,5-trimethylbenzene in the presence of $\mathrm{NO}_{\mathrm{x}}$ : effects of chemical structure on SOA aging. Atmos. Chem. Phys. 12 (10), 4667, 2012.

8. FRKA S., SALA M., KROFLIC A., HUS M., CUSAK A., GRGIC I. Quantum chemical calculations resolved identification of methylnitrocatechols in atmospheric aerosols. Environ. Sci. Technol. 50 (11), 5526, 2016.

9. JI Y.M., ZHAO J., TERAZONO H., MISAWA K., LEVITT N.P., LI Y.X., LIN Y., PENG J.F., WANG Y., DUAN L., Pan, B., ZHANG F., FENG X.D., AN T.C., MARREROORTIZ W., SECREST J., ZHANG A.L., SHIBUYA K., MOLINA M.J., ZHANG R.Y. Reassessing the atmospheric oxidation mechanism of toluene. P. Natl. Acad. Sci. USA, 114 (31), 8169, 2017.

10. YUAN B., LIGGIO J., WENTZELL J., LI S.M., STARK H., ROBERTS J.M., GILMAN J., LERNER B.,WARNEKE C., LI R., LEITHEAD A., OSTHOFF H. D., WILD R., BROWN S.S., DE GOUW J.A. Secondary formation of 
nitrated phenols: insights from observations during the Uintah Basin Winter Ozone Study (UBWOS) 2014. Atmos. Chem. Phys. 16 (4), 2139, 2016.

11. LASKIN A., LASKIN J., NIZKORODOV S.A. Chemistry of atmospheric brown carbon. Chem. Rev. 115 (10), 4335, 2015.

12. XIE M.J., CHEN X., HAYS M.D., LEWANDOWSKI M., OFFENBERG J., KLEINDIENST T.E., HOLDER A.L. Light absorption of secondary organic aerosol: composition and contribution of nitroaromatic compounds. Environ. Sci. Technol. 51 (20), 11607, 2017.

13. LIN P., LIU J.M., SHILLING J.E., KATHMANN S.M., LASKIN J., LASKIN A. Molecular characterization of brown carbon $(\mathrm{BrC})$ chromophores in secondary organic aerosol generated from photo-oxidation of toluene. Phys. Chem.Chem. Phys. 17 (36), 23312, 2015.

14. WANG Y.J., HU M., WANG Y.C., ZHENG J., SHANG D.J., YANG Y.D., LIU Y., LI X., TANG R.Z., ZHU W.F., DU Z.F., WU Y.S., GUO S., WU Z.J., LOU S.R., HALLQUIST M., YU J.Z. The formation of nitroaromatic compounds under high $\mathrm{NO}_{\mathrm{x}}$ and anthropogenic VOC conditions in urban Beijing, China. Atmos. Chem. Phys. 19 (11), 7649, 2019.

15. AL-NAIEMA I.M., OFFENBERG J.H., MADLER C.J., LEWANDOWSKI M., KETTLER J., FANG T., STONE E.A. Secondary organic aerosols from aromatic hydrocarbons and their contribution to fine particulate matter in Atlanta, Georgia. Atmos. Environ. 223 (117227), $1,2020$.

16. VIONE D., MAURINO V., MINERO C., LUCCCHIARI M., PELIZZETTI E. Nitration and hydroxylation of benzene in the presence of nitrite/nitrous acid in aqueous solution. Chemosphere 56 (11), 1049, 2004.

17. KROFLIC A., HUS M., GRILC M., GRGIC I. Underappreciated and complex role of nitrous acid in aromatic nitration under mild environmental conditions: the case of activated methoxyphenols. Environ. Sci. Technol. 52 (23), 13756, 2018.

18. VIDOVIĆ K., LAŠIČ JURKOVIĆ D., SALA M., KROFLIČ A., GRGIĆ I. Nighttime aqueous-phase formation of nitrocatechols in the atmospheric condensed phase. Environ. Sci. Technol. 52 (17), 9722, 2018.

19. XU Q.C., WANG S.X., JIANG J.K., BHATTARAI N., LI X.X., CHANG X., QIU X.H., ZHENG M., HUA Y., HAO J.M. Nitrate dominates the chemical composition of $\mathrm{PM}_{2.5}$ during haze event in Beijing, China. Sci. Total Environ. 689, 1293, 2019.

20. LI M., KLIMONT Z., ZHANG Q., MARTIN R.V., ZHENG B., HEYES C., COFALA J., ZHANG Y.X., HE K.B. Comparison and evaluation of anthropogenic emissions of $\mathrm{SO}_{2}$ and $\mathrm{NO}_{x}$ over China. Atmos. Chem. Phys. 18 (5), 3433, 2018.

21. SUN Z.L., DUAN F.K., He, K.B., DU J.J., ZHU L.D. Sulfate-nitrate-ammonium as double salts in $\mathrm{PM}_{2.5}$ : Direct observations and implications for haze events. Sci. Total. Environ. 647, 204, 2019.

22. SHAO P.Y., TIAN H.Z., SUN Y.J., LIU H.J., WU B.B., LIU S.H., LIU X.G., WU Y.M., LIANG W.Z., WANG Y.,GAO J.J., XUE Y.F., BAI X.X., LIU W., LIN S.M., HU G.Z. Characterizing remarkable changes of severe haze events and chemical compositions in multi-size airborne particles $\left(\mathrm{PM}_{1}, \mathrm{PM}_{2.5}\right.$ and $\left.\mathrm{PM}_{10}\right)$ from January 2013 to 2016-2017 winter in Beijing, China. Atmos. Environ. 189, 133, 2018.

23. WANG J., ZHANG J.S., LIU Z. J., WU J., ZHANG Y.F., HAN S.Q., ZHENG X.J., ZHOU L.D., FENG Y.C. ZHU
T. Characterization of chemical compositions in sizesegregated atmospheric particles during severe haze episodes in three mega-cities of China. Atmos. Res. 187, 138, 2017.

24. GE S.S., XU Y.F., JIA L. Effects of inorganic seeds on secondary organic aerosol formation from photochemical oxidation of acetone in a chamber. Atmos. Environ. 170, 205, 2017.

25. VIONE D., MAURINO V., MINERO C., PELIZZETTI E., HARRISON M.A.J., OLARIUC R.I., ARSENER C. Photochemical reactions in the tropospheric aqueous phase and on particulate matter. Chem. Soc. Rev. 35 (5), 441, 2006.

26. HUANG M.Q., HAO L.Q., CAI S.Y., GU X.J., ZHANG W.X., HU C.J., WANG Z.Y., FANG L., ZHANG W.J. Effects of inorganic seed aerosols on the particulate products of aged 1,3,5-trimethylbenzene secondary organic aerosol. Atmos. Environ. 152, 490, 2017.

27. HUANG M.Q., XU J., CAI S.Y., LIU X.Q., HU C,J., GU X,J., ZHAO W.X., FANG L., ZHANG W.J. Mass spectral analysis of the aged 1,3,5-trimethyl benzene secondary organic aerosol in the presence of ammonium sulfate seeds. Pol. J. Environ. Stud. 26 (4), 1531, 2017.

28. XU J., HUANG M.Q., FENG Z.Z., CAI S.Y., ZHAO W.X., HU C,J., GU X,J., ZHANG W.J. Effects of inorganic seed aerosol on the formation of nitrogen- containing organic compounds from reaction of ammonia with photooxidation products of toluene. Pol. J. Environ. Stud. 29 (1), 907, 2020.

29. ASSAF E., FITTSCHEN C. Cross section of OH radical overtone transition near $7028 \mathrm{~cm}^{-1}$ and measurement of the rate constant of the reaction of $\mathrm{OH}$ with $\mathrm{HO}_{2}$ radicals. J. Phys. Chem. A 120 (36), 7051, 2016.

30. FENG Z.Z., HUANG M.Q., CAI S.Y., XU X.Z., YANG Z.L., ZHAO W.X., HU C.J., GU X,J., ZHANG W.J. Characterization of single scattering albedo and chemical components of aged toluene secondary organic aerosol. Atmos. Pollut. Res. 10 (6), 1736, 2019.

31. UPDYKE K.M., NGUYEN T.B., NIZKORODOV S.A. Formation of brown carbon via reactions of ammonia with secondary organic aerosols from biogenic and anthropogenic precursors. Atmos. Environ. 63, 22, 2012.

32. POWELSON M.H., ESPELIEN B.M, HAWKINS L.N., GALLOWAY M.M., DE HAAN D.O. Brown carbon formation by aqueous-phase carbonyl compound reactions with amines and ammonium sulfate $[\mathrm{J}]$. Environ. Sci. Technol. 48 (2), 985, 2014.

33. HUANG M.Q., ZHANG J.H., CAI S.Y., LIAO Y.M., ZHAO W.X., HU C.J., GU X.J., FANG L., ZHANG W.J. Characterization of particulate products for aging of ethylbenzene secondary organic aerosol in the presence of ammonium sulfate seed aerosol. J. Environ. Sci. 47, 219, 2016.

34. JATHAR S.H., MAHMUD A., BARSANTI K.C., ASHER W.E., PANKOW J.F., KLEEMAN M.J. Water uptake by organic aerosol and its influence on gas/particle partitioning of secondary organic aerosol in the United States. Atmos. Environ. 129, 142, 2016.

35. ATKINSON R., AREY J. Atmospheric degradation of volatile organic compounds. Chem. Rev. 103 (12), 4605, 2003.

36. SATO K., TAKAMI A., ISOZAKI T., HIKIDA T., SHIMONO A., IMAMURA T. Mass spectrometric study of secondary organic aerosol formed from the photooxidation of aromatic hydrocarbons. Atmos. Environ. 44, $22,2010$. 
37. FAN J.F., ZHANG R.Y. Atmospheric oxidation mechanism of p-xylene: A density functional theory study. J. Phys. Chem. A 110 (24), 7728, 2006.

38. CARLTON A.G., TURPIN B.J., ALTIERI K.E., SEITZINGER S., REFF A., LIM H.J., ERVENS B. Atmospheric oxalic acid and SOA production from glyoxal: Results of aqueous photo-oxidation experiments. Atmos. Environ. 41 (35), 7588, 2007.

39. MOISE T., FLORES J.M., RUDICH Y. Optical Properties of Secondary Organic Aerosols and Their Changes by Chemical Processes. Chem. Rev. 115 (10), 4400, 2015.

40. CHAKRABARTY R.K., MOOSMLLER H., CHEN L.W.A., LEWIS K., ARNOTT W.P., MAZZOLENI C., DUBEY M.K., WOLD C.E., HAO W.M., KREIDENWEIS S.M. Brown carbon in tar balls from smoldering biomass combustion. Atmos.Chem. Phys. 10 (13), 6363, 2010.
41. NODA J., VOLKAMER R., MOLINA M.J. Dealkylation of alkylbenzenes: A significant pathway in the toluene, o-, $\mathrm{m}-, \mathrm{p}-x y l e n e ~ p l u s \mathrm{OH}$ reaction. J. Phys. Chem. A 113 (35), 9658, 2009.

42. HALLQUIST M., WENGER J., BALTENSPERGER U., RUDICH Y., SIMPSON D., CLAEYS M., DOMMEN J., DONAHUE N.M., GEORGE C., GOLDSTEIN A.H. HAMILTON J.F., HERRMANN H., HOFFMANN T., IINUMA Y., JANG M., JENKIN M.E., JIMENEZ J.L., KIENDLER-SCHARR A., MAENHAUT W., MCFIGGANS G., MENTEL TH.F., MONOD A., PRÉVÔT A.S.H., SEINFELD J.H., SURRATT J.D., SZMIGIELSKI R., WILDT J. The formation, properties and impact of secondary organic aerosol: Current and emerging issues. Atmos. Chem. Phys. 9 (14), 5155, 2009. 